\title{
Modelling the response of the Lambert Glacier-Amery Ice Shelf system, East Antarctica, to uncertain climate forcing over the 21st and 22nd centuries
}

\author{
Y. Gong ${ }^{1,2}$, S. L. Cornford ${ }^{3}$, and A. J. Payne ${ }^{3}$ \\ ${ }^{1}$ School of Earth Sciences, University of Bristol, Bristol BS8 1RJ, UK \\ ${ }^{2}$ Arctic Center, Lapland University, 96101, Rovaniemi, Finland \\ ${ }^{3}$ School of Geographical Sciences, University of Bristol, Bristol BS8 1SS, UK \\ Correspondence to: S. L. Cornford (s.1.cornford@bristol.ac.uk)
}

Received: 23 October 2013 - Published in The Cryosphere Discuss.: 2 December 2013

Revised: 7 April 2014 - Accepted: 9 May 2014 - Published: 18 June 2014

\begin{abstract}
The interaction between the climate system and the large polar ice sheet regions is a key process in global environmental change. We carried out dynamic ice simulations of one of the largest drainage systems in East Antarctica: the Lambert Glacier-Amery Ice Shelf system, with an adaptive mesh ice sheet model. The ice sheet model is driven by surface accumulation and basal melt rates computed by the FESOM (Finite-Element Sea-Ice Ocean Model) ocean model and the RACMO2 (Regional Atmospheric Climate Model) and LMDZ4 (Laboratoire de Météorologie Dynamique Zoom) atmosphere models. The change of ice thickness and velocity in the ice shelf is mainly influenced by the basal melt distribution, but, although the ice shelf thins in most of the simulations, there is little grounding line retreat. We find that the Lambert Glacier grounding line can retreat as much as $40 \mathrm{~km}$ if there is sufficient thinning of the ice shelf south of Clemence Massif, but the ocean model does not provide sufficiently high melt rates in that region. Overall, the increased accumulation computed by the atmosphere models outweighs ice stream acceleration so that the net contribution to sea level rise is negative.
\end{abstract}

\section{Introduction}

Climate change can affect an ice sheet by altering its mass balance directly through surface accumulation and melting, or indirectly through melting and refreezing on the ice shelfocean interface and the consequential dynamic thickening and thinning (van den Broeke et al., 2009; Williams et al., 2011; Huybrechts and de Wolde, 1999). So far the retreat and disintegration of ice shelves in the west and east coasts of the Antarctica Peninsula as well as some of the dramatic thinning and elevation changes observed in Pine Island Glacier are associated with atmospheric and oceanic warming (Scambos et al., 2000; Skvarca et al., 1999; Joughin et al., 2003; Shepherd et al., 2002). Mass change over the ice sheet will in turn affect the global sea level (van den Broeke et al., 2009): the rate of sea-level rise due to the present-day mass loss from Antarctica is about $0.25 \mathrm{~mm} \mathrm{a}^{-1}$ for 2000-2011 (Shepherd et al., 2012). These concerns motivate the application of numerical models that attempt to simulate the current state of ice sheets and their response to future climate forcing.

As one of the largest ice drainage systems in Antarctica (Rignot and Thomas, 2002) the Lambert Glacier-Amery Ice Shelf (LG-AIS) system plays a crucial role in determining the future responses of East Antarctica to climate change as it drains about $16 \%$ of the grounded East Antarctica (Fricker et al., 2000). The grounded portion of the system is thought to be in balance or gaining mass according to numerous observations (Wen et al., 2006, 2008; Yu et al., 2010). At the same time, the Amery Ice Shelf interacts with the ocean cavity beneath resulting in complex patterns of melting and refreezing (Galton-Fenzi et al., 2012). In total, $50 \%$ of the mass (around $46.4 \pm 6.9 \mathrm{Gt} \mathrm{a}^{-1}$ ) leaves the ice shelf through basal melting (Wen et al., 2010), with the remainder lost through calving events at the northern edge (Yu et al., 2010).

AIS has a relatively narrow shape compared to the Ross Ice Shelf and the Ronne-Filchner Ice Shelf and its ice 


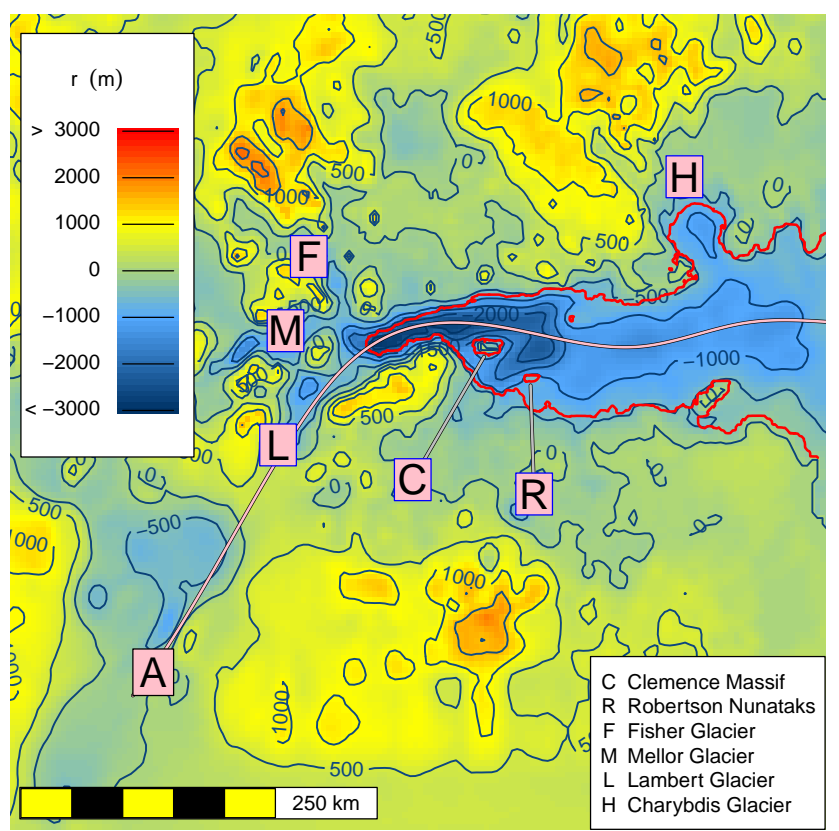

Figure 1. ALBMAP bedrock topography in the region of the Amery Ice Shelf. The grounding line (red curve) lies on a downward slope along its entire length. The Lambert, Fisher, and Mellor glaciers converge and join the ice shelf at its southern end. The curve marked "A" follows Lambert Glacier onto the ice shelf and is used for crosssection plots in Fig. 6.

shelf front only accounts for $1.7 \%$ of the total East Antarctic coastline (Budd et al., 1967). Several topographic features (Fig. 1) characterize the dynamics of AIS including Clemence Massif (Hambrey and Dowdeswell, 1994), which is an elongated, mostly ice-free massif located at the southeastern part of the ice shelf. Three large glaciers: Lambert, Fisher, and Mellor glaciers, converge at the ice shelf's southern tip.

The AIS has long been considered a stable ice shelf that is currently undergoing a natural advance-calve-advance cycle (Fricker et al., 2002). Observations of its mass balance (Wen et al., 2006, 2008; Yu et al., 2010) and model studies of the rift propagation process on its ice front (Larour et al., 2004; Bassis et al., 2005; MacAyeal et al., 2006) support that hypothesis. But the future state of the whole drainage system has large uncertainties under the influence of global warming and model studies can perhaps throw light on the future of the ice shelf and its adjacent glaciers.

In this study, we carried out dynamic simulations of the Amery Ice Shelf drainage basin, which includes the Lambert, Fisher and Mellor glaciers. Two factors govern the results of the projection when doing dynamic simulations. One is the input climatic forcing; the other one is the issue of whether the ice sheet model can properly capture the ice sheet flow. A set of previously published surface mass balance $(\mathrm{SMB})$ and basal melt-rate calculations were em- ployed as climate forcing in this study. Two higher resolution atmospheric models, LMDZ4 (Laboratoire de Météorologie Dynamique Zoom) (Agosta et al., 2013) and RACMO2 (Regional Atmospheric Climate Model) (Ligtenberg et al., 2013), and one ocean model, FESOM (Finite-Element SeaIce Ocean Model) (Timmerman and Helmer, 2014), are chosen to provide the SMB and basal melt rate respectively. They are driven by the boundary data computed by two global climate models, HadCM3 (Hadley Centre Coupled Model, version 3) and ECHAM5, which are in turn driven by the SRES (Special Report on Emissions Scenarios) greenhouse gas emissions scenarios E1 and A1B.

The ice sheet model used in this study employs adaptive mesh refinement (AMR) to obtain a non-uniform mesh that has a finer spatial resolution where dynamical features such as grounding line and fast flowing ice streams exist, and coarser resolution where fine resolution is unnecessary. As the resolution of the mesh evolves with time to follow the grounding line (Cornford et al., 2013), this model is well suited to studying grounding line migration and dynamic thinning in the region of the Amery Ice Shelf. In order to assess the response of the drainage system to uncertain climate forcing in 21 st and 22 nd centuries we consider

1. ice thickness and velocity change and grounding line migration

2. contribution to global sea level change

3. and the differing roles of accumulation and sub ice-shelf melting as well as the influence of topographic features on the dynamics of the system.

\section{Methodology}

\subsection{Ice sheet model}

The BISICLES adaptive mesh ice sheet model used in this study is described in detail in Cornford et al. (2013). It employs a vertically integrated model based on Schoof and Hindmarsh (2010) which includes longitudinal and lateral strains and a simplified treatment of vertical shear strain and is best suited to ice shelves and fast flowing ice streams. Ice is assumed to be in hydrostatic equilibrium so that given bedrock elevation $r$ and ice thickness $h$ the upper surface elevation $s$ is

$s=\max \left[h+r,\left(1-\frac{\rho_{\mathrm{i}}}{\rho_{\mathrm{w}}}\right) h\right]$,

in which $\rho_{\mathrm{i}}$ and $\rho_{\mathrm{w}}$ are the densities of ice and ocean water. The ice thickness $h$ and horizontal velocity $u$ satisfy a pair of two-dimensional partial differential equations, an ice transport equation,

$\frac{\partial h}{\partial t}+\nabla \cdot[\boldsymbol{u} h]=M_{\mathrm{s}}-M_{\mathrm{b}}$, 
where $M_{\mathrm{S}}$ and $M_{\mathrm{b}}$ are accumulation and melt rates, and a stress-balance equation,

$\nabla \cdot[\phi h \bar{\mu}(2 \dot{\epsilon}+2 \operatorname{tr}(\dot{\epsilon}) I)]+\tau^{\mathrm{b}}=\rho_{\mathrm{i}} g h \nabla s$,

where $\dot{\epsilon}$ is the horizontal rate-of-strain tensor,

$\dot{\epsilon}=\frac{1}{2}\left[\nabla \boldsymbol{u}+(\nabla \boldsymbol{u})^{T}\right]$

and $I$ is the identity tensor. The vertically integrated effective viscosity $\phi h \bar{\mu}$ is computed from the vertically varying effective viscosity $\mu$ through

$\phi h \bar{\mu}(x, y)=\phi \int_{s-h}^{s} \mu(x, y, z) \mathrm{d} z$,

where $\mu$ includes a contribution from vertical shear and satisfies

$2 \mu A(T)\left(4 \mu^{2} \dot{\epsilon}^{2}+|\rho i g(s-z) \nabla s|^{2}\right)^{(n-1) / 2}=1$,

where the flow rate exponent $n=3$ and $\phi$ is a stiffening factor (or, equivalently, $\phi^{-n}$ is an enhancement factor). $A(T)$ depends on the ice temperature $T$ through the Arrhenius law proposed by Hooke (1981),

$A(T)=A_{0} \exp \left(\frac{3 f}{\left(T_{r}-T\right)^{k}}-\frac{Q}{R T}\right)$,

where $A_{0}=0.093 \mathrm{~Pa}^{-3} \mathrm{a}^{-1}, \quad Q / R=9.48 \times 10^{3} \mathrm{~K}, \quad f=$ $0.53 \mathrm{~K}^{k}, k=1.17$ and $T_{r}=273.39 \mathrm{~K}$. Note that since we solve an inverse problem (described below) to find the unknown $\phi$, the precise form of $A(T)$ is not crucial. We make use of a linear viscous friction law, so that the basal traction is

$\tau^{\mathrm{b}}=\left\{\begin{array}{ll}-C u & \text { if } \frac{\rho_{\mathrm{i}}}{\rho_{\mathrm{w}}}>-r \\ 0 & \text { otherwise }\end{array}\right.$.

Like $\phi, C$ will be determined by solving an inverse problem.

Equations (2) and (3) are discretized, using the Chombo C++ toolkit (Colellaet al., 2013), on block-structured adaptive meshes that are modified throughout the simulation in order to maintain fine resolution along the grounding line and in ice streams, and coarser resolution elsewhere. Meshes having grid cells with $\Delta x=10,5,2.5,1.25$ or $0.625 \mathrm{~km}$ (a fivelevel mesh) are used for the main experiments in this study, and additional lower resolution meshes are used to demonstrate that the five-level meshes are adequate. Figure 4 shows a portion of a four-level mesh - one level coarser than used, because the higher resolution mesh is too dense to display centred on the AIS grounding line.

Ice thickness and bedrock topography data (Fig. 1) are drawn from the $5 \mathrm{~km}$ ALBMAP DEM (digital elevation model) (LeBrocq et al., 2010) and averaged or interpolated onto the block-structured meshes as required. The basic mask for the whole Antarctic is obtained from the Mosaic of Antarctic (MOA) coastline shape files (Haran et al., 2005; Scambos et al., 2007). Modifications have been made to the grounding line in order to smoothly combine the grounded ice sheet, which is largely from BEDMAP data sets (Lythe et al., 2001), with the ice shelf. The basal topography and marine bathymetry is based on the BEDMAP data sets but more data have been provided in ALBMAP data sets, especially bathymetry underneath ice shelves. The ice thickness data of grounded ice is produced through incorporation of the original BEDMAP ice thickness and the AGASEA/BBAS data for West Antarctic (Vaughan et al., 2006; Holt et al., 2006).

All of the simulations are carried out on a rectangular domain. Figure 2 shows the full extent of this domain, and the drainage basin of the AIS within it. The region outside the drainage basin is used only to provide boundary conditions at the ice divide, and throughout this paper ice sheet volume above flotation, surface mass balance, and melt-rate statistics are reported with respect to the drainage basin only.

We need to provide a basal friction coefficient field $C(x, y)$ along with temperature and stiffening factor fields $T(x, y, z)$ and $\phi(x, y)$ to solve Eq. (3). Ice temperature data is provided by a three-dimensional thermomechanical higher-order model (Pattyn, 2010), while the basal friction and stiffening coefficients inside the drainage basin are found by solving an inverse problem. We seek to minimize the difference between the magnitude of modelled velocity and velocity data taken from InSAR (interferometric synthetic aperture radar) observations acquired during the years 2007 to 2009 (Rignot et al., 2011), using an optimization method similar to that of MacAyeal (1992), Joughin et al. (2009) and Morlighem et al. (2010). Outside the drainage basin we set $C(x, y)=10^{5} \mathrm{~Pa} \mathrm{~m}^{-1}$, which in effect means no flow across the ice divide, and $\phi=1$. Figure 2 shows the observed ice speed and the modelled speed at the start of the simulation side by side.

Having matched the velocity observations, we find highfrequency variation in the ice thinning (or thickening) rates, which are assumed to be artifacts of interpolation and other sources of error in the ice sheet geometry (Morlighem et al., 2011; Seroussi et al., 2011), or mismatch between the time at which the geometry and velocity were observed. So before carrying out all the targeted experiments we run (relax) the model for a period with a present-day forcing to bring it closer to a steady state. The relaxation is carried out in two stages. First we set the SMB to the 20002009 mean from a high-resolution atmosphere model (the HadCM3/E1/RACMO2 data described in Sect. 2.2), and the sub-shelf melt rate is chosen to keep the ice shelf in steady state. After 50 years, we compute an accumulation rate $M_{s}^{0}$ required to keep the grounded ice in steady state, and a melt rate $M_{\mathrm{b}}^{0}$ that will keep the ice shelf close to steady state. We then run the model for 50 years starting again from the original state with the achieved accumulation and melt rate. The resulting ice sheet is closer to, but not at, equilibrium, and we 

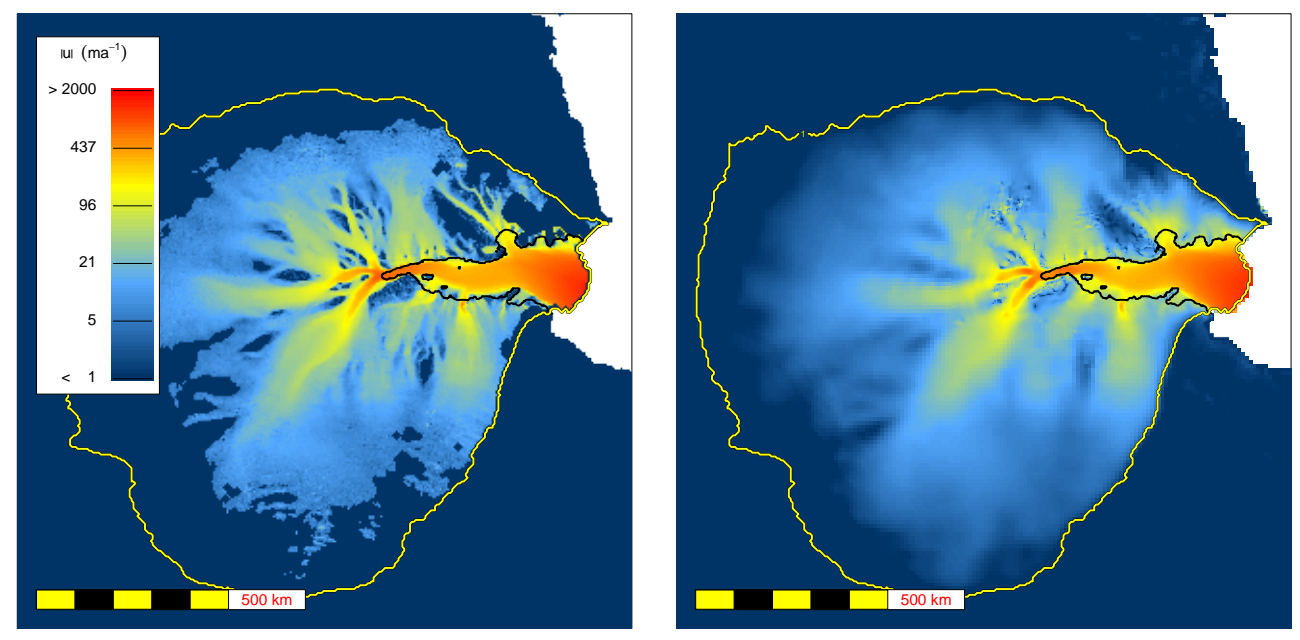

Figure 2. Rignot et al. (2011) observed (left) ice flow speed over the AIS drainage basin (top) and BISICLES ice flow speed over the whole computational domain (right). The present-day drainage basin boundary and grounding line are indicated by solid contours.

carry out all projections starting from this state, with SMB and melt rates computed by adding the perturbations described in the next section to $M_{\mathrm{s}}^{0}$ and $M_{\mathrm{b}}^{0}$. Absent any perturbations, the drainage basin gains mass at a rate of $5 \mathrm{~km}^{3} \mathrm{a}^{-1}$.

The melt rate is decomposed into grounding line localized and ambient components. Higher melt rates are expected close to the grounding line and are required to keep the ice shelf there in steady state. On top of that, flowline calculations indicate that elevated melt rates close to the grounding line can result in a dynamic response quite different from the response to elevated melt some distance downstream (Walker et al., 2008; Gagliardini et al., 2010). We construct a scheme that allows higher melt rates to follow the grounding line by setting

$$
\begin{aligned}
M_{\mathrm{b}}^{0}(x, y, t) & =M_{\mathrm{GL}}(x, y) p(x, y, t) \\
& +M_{\mathrm{A}}(x, y)(1-p(x, y, t)),
\end{aligned}
$$

where $p=1$ at the grounding line and decays exponentially with distance from it. The components $M_{\mathrm{GL}}$ and $M_{\mathrm{A}}$ are determined by considering the ice mass flux in regions close to and far from the initial grounding line respectively, smoothed to remove short wavelength features, and then extrapolated into the surrounding regions. The ambient melt-rate coefficient $R_{\mathrm{A}}$ is calculated from the mass flux divergence far from the grounding line:

$$
R_{\mathrm{A}}(x, y)= \begin{cases}\nabla .(u h) & \text { if } p(x, y, t=0)<\frac{1}{100} \\ 0 & \text { otherwise. }\end{cases}
$$

This field then forms the right-hand side to a parabolic equation,

$$
\frac{\partial M_{\mathrm{A}}^{\prime}}{\partial s}+M_{\mathrm{A}}^{\prime}-\lambda^{2} \nabla^{2} M_{\mathrm{A}}^{\prime}=-R_{\mathrm{A}},
$$

which is integrated with respect to the time-like parameter $s$ to find a value $M_{\mathrm{A}}(x, y)=M_{\mathrm{A}}^{\prime}(x, y, S)$. Given a largeenough $S$, the effect is to extrapolate $-R_{\mathrm{A}}(x, y)$ across the domain and at the same time smooth it over the length scale $\lambda=12.8 \mathrm{~km}$. A similar extrapolation and smoothing procedure is followed to compute $M_{\mathrm{GL}}(x, y)$, using the same parabolic equation but with a different right-hand side:

$R_{\mathrm{GL}}(x, y)= \begin{cases}\frac{1}{p}\left[\nabla \cdot(\boldsymbol{u} h)-(p-1) M_{A}(x, y)\right] & \text { if } p<1 \\ 0 & \text { otherwise. }\end{cases}$

Figure 3 shows the initial melt rate computed in this way.

\subsection{Climate forcing}

Future climate forcings were derived from the atmosphere and ocean models by computing space- and time-dependent anomalies with respect to the 1980-1990 mean, and adding them to the base accumulation and melt rates described in Sect. 2.1. Such an approach was necessary because the climate models are not in close agreement at the start of the calculation, nor are they in equilibrium with the ice sheet. Both accumulation and melt rates increase over the simulation period, but there is considerable variation, with the HadCM3 scenarios leading to far higher melt rates than the ECHAM5 scenarios (which show essentially no increase in melt rates from the present day) and LMDZ4 producing significantly more accumulation over the AIS drainage basin than RACMO. The accumulation anomalies are summarized in Table 1, and the melt-rate anomalies in Table 2.

The resulting SMB and melt anomalies drive seven basic simulation cases combining the FESOM melt rates with the LMDZ4 and RACMO accumulation rates for each global climate model and emissions scenario. We named each of these after the climate data that drives it. For example, HadCM3/A1B/RACMO2/FESOM combines the HadCM3/A1B/RACMO2 surface mass balance 
Table 1. The 21 st and 22nd century mean surface mass balance anomalies with respect to the $1980-1990$ mean, integrated over the presentday drainage basin

\begin{tabular}{|c|c|c|c|c|}
\hline \multirow[b]{2}{*}{ Model } & \multicolumn{2}{|c|}{$\begin{array}{c}\text { Grounded } \\
\text { mean SMB }\left(\mathrm{km}^{3}\right)\end{array}$} & \multicolumn{2}{|c|}{$\begin{array}{c}\text { Floating } \\
\text { mean SMB }\left(\mathrm{km}^{3}\right)\end{array}$} \\
\hline & $2000-2100$ & $2100-2200$ & $2000-2100$ & $2100-2200$ \\
\hline HadCM3/A1B/RACMO2 & 1.80 & 12.4 & -0.57 & 0.27 \\
\hline HadCM3/A1B/LMDZ4 & 14.6 & 50.6 & -5.79 & -2.37 \\
\hline HadCM3/E1/RACMO2 & -1.25 & 1.62 & -0.94 & -0.42 \\
\hline HadCM3/E1/LMDZ4 & 14.3 & 11.4 & -1.56 & -2.40 \\
\hline ECHAM5/A1B/RACMO2 & 4.62 & N/A & 0.89 & N/A \\
\hline ECHAM5/A1B/LMDZ4 & N/A & N/A & N/A & N/A \\
\hline ECHAM5/E1/RACMO2 & 1.03 & N/A & 0.35 & N/A \\
\hline ECHAM5/E1/LMDZ4 & 2.40 & N/A & -1.6 & N/A \\
\hline
\end{tabular}

Table 2. The 21st and 22nd century melt-rate anomalies with respect to the 1980-1990 mean, integrated over the floating portion of the present-day drainage basin

\begin{tabular}{lrr}
\hline \multirow{2}{*}{ Model } & \multicolumn{2}{c}{ Mean melt-rate anomaly $\left(\mathrm{km}^{3}\right)$} \\
2000-2100 & 2100-2200 \\
\hline HadCM3/A1B/FESOM & 32.1 & 262 \\
HadCM3/E1/FESOM & 27.0 & 121 \\
\hline ECHAM5/A1B/FESOM & 3.17 & N/A \\
ECHAM5/E1/FESOM & 1.90 & N/A \\
\hline
\end{tabular}

with the HadCM3/A1B/FESOM melt-rate anomalies. Note that only HadCM3/A1B simulations are available for the full 220 years: ECHAM5 simulations ran only until 2100 and E1/FESOM simulations until 2150. There are no ECHAM5/A1B/LMDZ4 data. Two further simulations were added to these seven basic cases: a control calculation with no anomalies, and HadCM3/A1B/None/FESOM, which was constructed from the HadCM3/A1B/FESOM melt rates with no accumulation anomaly applied.

Melt-rate anomalies computed from the FESOM data have an obvious shortcoming. Since the FESOM calculations assumed the AIS remained in its present-day configuration, no melt-rate anomaly is computed for regions behind the present-day grounding lines, which however becomes afloat during the course of the ice sheet model simulation. Given that the melt rate close to the grounding line is usually considered to be important (Walker et al., 2008; Gagliardini et al., 2010), we considered this source of error by constructing one further set of calculations (HadCM3/A1B/None/FESOM+), where the $\mathrm{HadCM} 3 / \mathrm{A} 1 \mathrm{~B} / \mathrm{FESOM}$ melt data is extrapolated into any newly floating regions by setting the melt rate there to the maximum value found in the original data within $100 \mathrm{~km}$. The resulting distribution of melt rates over the ice shelf is shown for the years $2100 \mathrm{CE}$ (common era) and 2200 CE in Fig. 3 alongside the original data for the year 2200 CE.

In summary, we carried out total of ten climate-forced experiments: the seven combinations defined by the surface mass balance and melt-rate anomalies summarized in Tables 1 and 2, two experiments with melt-rate anomalies but no accumulation anomaly, and a control run. The basic experiments ran from 1982 till at least 2100, or further if the forcing data was available. The HadCM3/A1B and control experiments ran till $2200 \mathrm{CE}$ and the HadCM3/E1 experiments till $2150 \mathrm{CE}$, while all of the ECHAM5 experiments ran till $2100 \mathrm{CE}$.

\subsection{Extreme forcing}

We investigated the degree to which the Amery Ice Shelf buttresses the glaciers at its southern edge by carrying out a set of progressively more extreme ice-shelf collapse experiments. In each of these, we imposed melt rates of $1000 \mathrm{~m} \mathrm{a}^{-1}$ over a portion of the ice shelf, effectively removing that part of the shelf entirely within a few years. These are of course unrealistic melt rates, and are intended only to allow us to determine which (if any) parts of the ice shelf are important in maintaining the tributary glaciers in equilibrium. In the most extreme case, experiment $\mathrm{S}_{0}$, these high melt rates are applied over the entire ice shelf, including regions that unground during the course of the simulation, while in cases $\mathrm{S}_{1}-\mathrm{S}_{5}$ the ice-shelf region north of an east-west line (shown in Fig. 9) disappears.

\section{Results and discussion}

\subsection{Mesh refinement}

Before considering the sensitivity to climate forcing, we must demonstrate that our chosen meshes, with the finest resolution $\Delta x_{\min }=0.625 \mathrm{~km}$, are adequate. Figures 4 and 5 show the results of the HadCM3/A1B/None/FESOM+ 

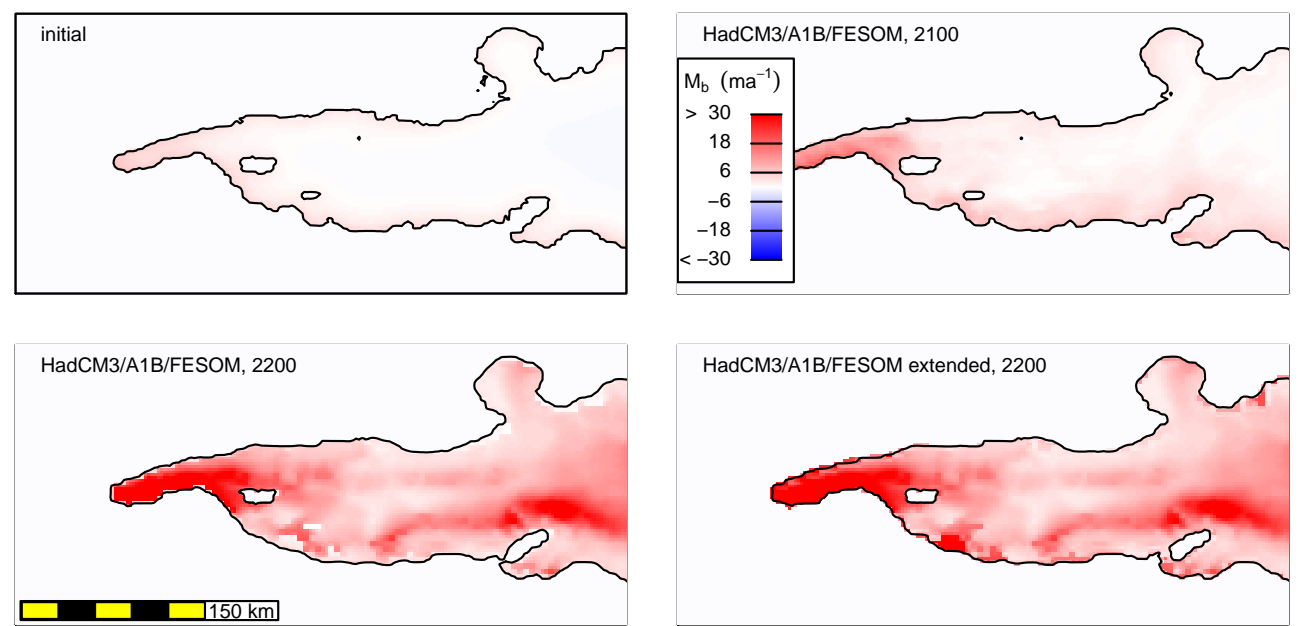

Figure 3. Initial melt-rate distribution $M_{\mathrm{b}}^{0}(x, y, t=1982)$ and HadCM3/A1B/FESOM melt rates $M_{\mathrm{b}}(x, y, t)$ for the years 2100 and 2200 . $M_{\mathrm{b}}^{0}(x, y, t)$ is computed from Eq. (9) to maintain elevated melt rates close to the grounding line. Time-dependent melt $M_{\mathrm{b}}(x, y, t)$ rates are computed by adding anomalies, computed with respect to the 1980-1990 mean, to $M_{\mathrm{b}}^{0}(x, y, t)$. The HadCM3/A1B/FESOM-extended melt-rate anomalies are constructed as the ice sheet evolves by extrapolating the HadCM3/A1B/FESOM data into floating regions outside the present-day ice shelf.

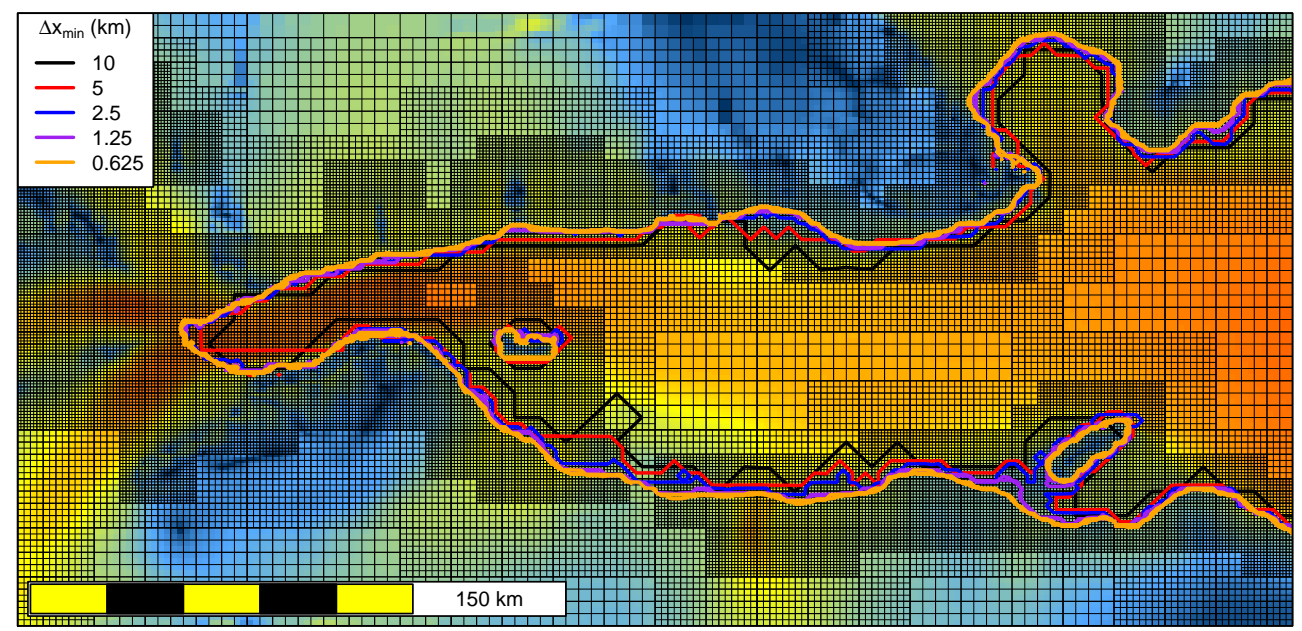

Figure 4. Mesh resolution and grounding line migration. Grounding lines in the year 2200 are plotted for HadCM3/A1B/None/FESOM+ simulations carried out on AMR meshes with the finest resolution $\Delta x_{\min }$ ranging from $10 \mathrm{~km}$ to $625 \mathrm{~m}$. The grounding lines are convergent with resolution: there is very little difference between the higher resolution results, and somewhat more between the lower resolution calculations. The mesh shown is from a $\Delta x_{\min }=1.25 \mathrm{~km}$ calculation (finer meshes are too dense to plot).

experiment carried out on a sequence of meshes with progressively smaller $\Delta x_{\min }$. The final position of the grounding line (Fig. 4) varies only a little from the coarsest $\left(\Delta x_{\min }=10 \mathrm{~km}\right)$ to the finest $\left(\Delta x_{\min }=625 \mathrm{~m}\right)$ resolutions, although some change is evident, in particular at coarser resolution. The rate of convergence with mesh resolution is more obvious in a plot of the volume above flotation (VAF) against time (Fig. 5). At the coarsest resolution, VAF grows by around $3000 \mathrm{~km}^{3}$ (9 mm sea level equivalent) over 220 years, while at the finest resolution it grows by around $600 \mathrm{~km}^{3}$ and then shrinks to yield a $-76 \mathrm{~km}^{3}$ net change by
2200. The second-finest resolution $\left(\Delta x_{\min }=1.25 \mathrm{~km}\right)$ shows a similar result, and differs from the $\Delta x_{\min }=0.625 \mathrm{~km}$ net VAF increase by $140 \mathrm{~km}^{3}$ and the $\Delta x_{\min }=2.5 \mathrm{~km}$ VAF increase by $300 \mathrm{~km}^{3}$. This is indicative of a first-order rate of convergence with $\Delta x_{\min }$ and allows us to estimate the truncation error for the $\Delta x_{\min }=0.625 \mathrm{~km}$ net VAF increase to be around $150 \mathrm{~km}^{3}$. That is a fraction of the difference between the $625 \mathrm{~m} \mathrm{HadCM} 3 / \mathrm{A} 1 \mathrm{~B} / \mathrm{None} / \mathrm{FESOM}+$ and HadCM3/A1B/RACMO2/FESOM VAF increase $\left(1300 \mathrm{~km}^{3}\right)$, a fraction of the difference between the time- and space-integrated HadCM3/A1B/RACMO2 and 


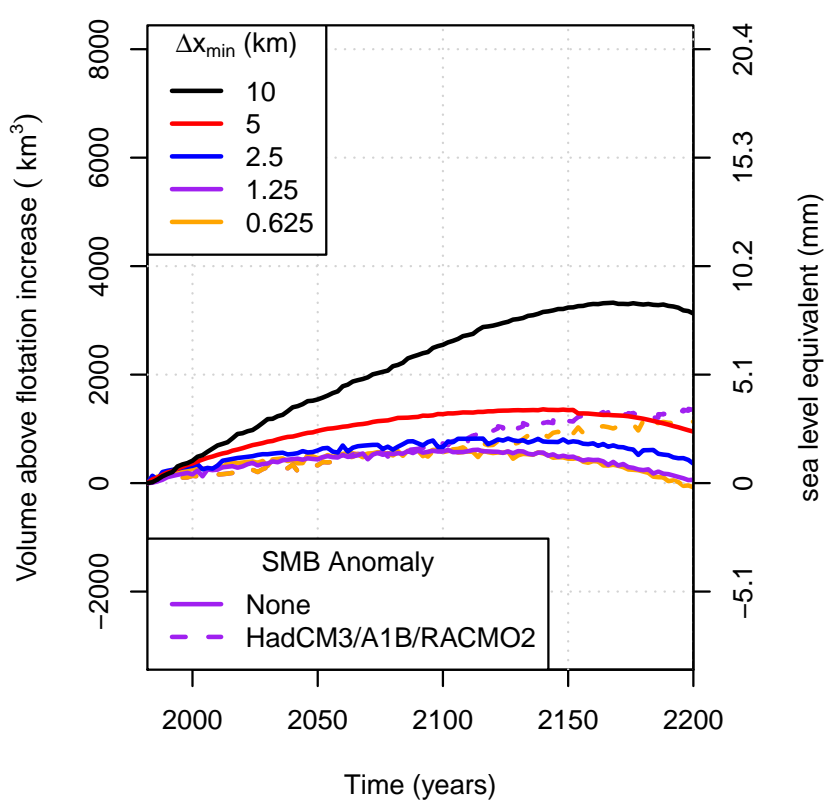

Figure 5. Mesh resolution and volume above flotation for the HadCM3/A1B/None/FESOM+ simulations. The importance of fine-mesh resolution is perhaps clearer in the evolution of volume above flotation than in grounding-line position. The coarsest resolution calculation results in $10 \mathrm{~mm}$ of sea level fall over 220 years, while the finest resolution calculations results in a $2 \mathrm{~mm}$ fall over the first century and a $2 \mathrm{~mm}$ rise in the second. The difference between curves with finest mesh spacing $\Delta x_{\min }$ and $2 \Delta x_{\min }$ decays with $\Delta x_{\min }$. Only when $\Delta x_{\min } \leq 1.25 \mathrm{~km}$ is the difference between successive curves much smaller than the difference caused by a change in forcing - in this case switching from no SMB anomalies to $\mathrm{HadCM} 3 / \mathrm{A} 1 \mathrm{~B} / \mathrm{RACMO} 2$ anomalies.

HadCM3/A1B/LMDZ4 surface mass balance anomalies $\left(5100 \mathrm{~km}^{3}\right)$, and a fraction of the VAF increase in the control run $\left(1100 \mathrm{~km}^{3}\right)$.

\subsection{Dynamic response to climate model forcing}

Evolution of the model ice flow dynamics is essentially determined by the melt-rate data. Although the HadCM3/A1B/LMDZ4/FESOM and HadCM3/A1B/RACMO2/FESOM simulations experience quite different accumulations over the 22nd century (an average of 50.6 vs. $12.4 \mathrm{~km}^{3} \mathrm{a}^{-1}$ ), they undergo similar patterns of change. Figure 6 shows a cross section of the ice sheet and its velocity running along Lambert Glacier and onto the ice shelf, and it is clear that in both cases the ice shelf evolves in the same way, with the majority of the thinning - around $500 \mathrm{~m}$ - taking place in the 22nd century when the FESOM melt rates are higher. The dynamic response to this thinning is deceleration over most of the ice shelf, but acceleration close to the southern section of the grounding line, both in the ice shelf and in the glaciers upstream.
As the tributary glaciers accelerate they lose some mass to the ice shelf, a trend which is evident for the HadCM3/A1B/None/FESOM and HadCM3/A1B/None/FESOM+ simulations in Fig. 7. The HadCM3/A1B/FESOM melt-rate anomalies are modest up until 2100 and increase thereafter (Fig. 3, Table 2). As a result, volume above flotation in these two simulations increases by 530 and $570 \mathrm{~km}^{3}$ respectively $(1.6 \mathrm{~mm}$ sea level equivalent) in the $21 \mathrm{st}$ century, compared to $680 \mathrm{~km}^{3}$ in the control simulation, and then decreases by 630 and $650 \mathrm{~km}^{3}$ $(1.8 \mathrm{~mm}$ sea level equivalent) in the following century, against a further $430 \mathrm{~km}^{3}$ increase in the control simulation.

At the same time, none of the climate-forced simulations exhibit significant grounding line migration. Figure 8 . shows the final grounding lines for those simulations that run until 2200 , and although the grounding line has retreated in all but the control case, the distance retreated is less than $5 \mathrm{~km}$ along much of its length, including the Lambert Glacier trunk in the south and Charybdis Basin in the west. Only at a few locations along the eastern section does the grounding line retreat more, by up to $10 \mathrm{~km}$.

Note that despite its extrapolation of FESOM melt rates into regions that float during the course of the simulation, the HadCM3/A1B/None/FESOM+ simulation shows the same dynamical response as the HadCM3/A1B/None/FESOM simulation. There is essentially no difference in either the final shape of the grounding line or the plot of volume above flotation against time. This does not suggest that the distribution of melt rate is not important, since the grounding line does not retreat far at all and the unaltered FESOM melt rates remain elevated close to the grounding line even without extrapolation.

\subsection{Dynamic response to extreme forcing}

Since the ice shelf thins considerably over the course of the climate-forced simulations, and in particular the northern section of the ice shelf all but disappears, we might have expected the Lambert, Mellor and Fisher glacier grounding lines to have retreated more dramatically. The southern grounding line should be buttressed to some extent by the whole ice shelf and, in general, thinning of the ice shelf should lead to immediate acceleration and thinning of the ice sheet (Dupont and Alley, 2005) and perhaps grounding line retreat (Rignot and Thomas, 2002).

The extreme ice-shelf removal experiments allow us to consider which parts of the ice shelf buttress the southern glaciers in some more detail. The final grounding lines for these experiments are shown in Fig. 9. If the ice-shelf removal is restricted to an area north of Clemence Massif, as in experiments $S_{3}, S_{4}$ and $S_{5}$, then the southern grounding line does not retreat by more than the $5 \mathrm{~km}$ seen in the FESOMforced experiments, although there is significant retreat in the area of the Charybdis Basin. However, if the ice shelf is removed over a region south of Clemence Massif, then there 


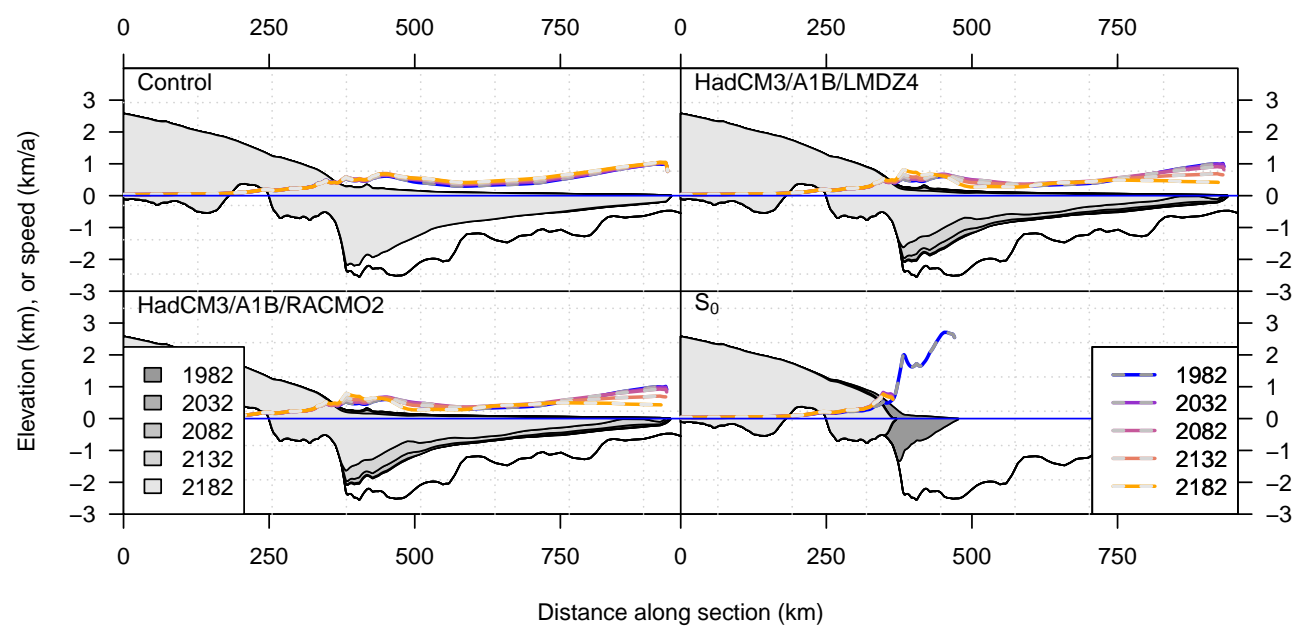

Figure 6. Cross-section plots of ice sheet geometry and velocity. The cross section follows Lambert Glacier onto the ice shelf, and on to the calving front and is shown in Figs. 1 and 8. Simulation year is indicated by a greyscale for then geometry, and colours for the speed. The ice shelf remains stable in the control run, and thins in all the FESOM-forced runs. The HadCM3/A1B/LMDZ4 simulation shows the same pattern of thinning and velocity change over 200 years as the HadCM3/A1B/RACMO2 simulation, despite the factor of 4 difference in accumulation anomalies (see Table 1).

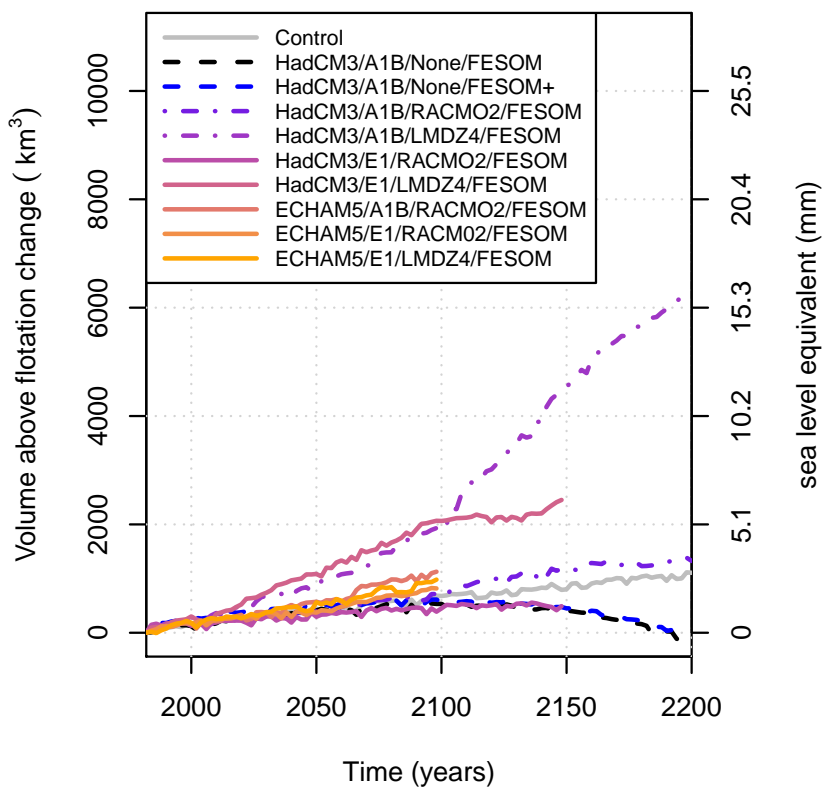

Figure 7. Evolution of the volume above flotation due to climate model forcing. Simulations up to 2100 lead to up to $5 \mathrm{~mm}$ of sea level fall in excess of the control run. Dynamic thinning in response to increased FESOM ocean forcing during the 22nd century leads to $3 \mathrm{~mm}$ of sea level rise by 2200 in the absence of increased accumulation (HadCM3/A1B/None/FESOM,HadCM3/A1B/None/FESOM+), but this figure is balanced by the HADCM/A1B/RACMO2 surface mass balance anomalies, and easily outweighed by the HADCM/A1B/LMDZ4 anomalies to give $15 \mathrm{~mm}$ of sea level fall. is a step change in the grounding-line retreat. The difference between experiments $S_{3}$ and $S_{4}$ is the removal of a $2500 \mathrm{~km}^{2}$ area of shelf immediately downstream of the massif, and both lead to a $5 \mathrm{~km}$ retreat at the southern end of the ice shelf. The difference between experiments $S_{2}$ and $S_{3}$ is the removal of a further $2500 \mathrm{~km}^{2}$ area of shelf around and upstream of the massif, yet the grounding-line retreat leaps from less than $5 \mathrm{~km}$ in case $S_{3}$ to around $25 \mathrm{~km}$ in case $S_{2}$. The most extreme cases, $S_{1}$ and $S_{0}$, remove ice from part or all of the narrow channel south of Clemence Massif, and see 30 and $45 \mathrm{~km}$ of grounding-line retreat respectively.

The same step change can be seen in a plot of mass loss over 200 years (Fig. 10). All of the extreme simulations show greater rates of mass loss than the climate-forcing experiments, with the exception of the $\mathrm{S}_{5}$ perturbation which loses a $3 \mathrm{~mm}$ sea level equivalent over 200 years; however, once again experiments $S_{3}$ and $S_{4}$ result in the same trend, both losing around $5 \mathrm{~mm}$, while $\mathrm{S}_{2}$ loses an additional $3 \mathrm{~mm}$. Experiments $S_{1}$ and $S_{0}$ lose a further 6 and $9 \mathrm{~mm}$.

The step change in retreat between experiments $S_{3}$ and $S_{2}$ coincides with a rapid change in the width of the fast flow. From the southern tip of the shelf to around $50 \mathrm{~km}$ south of the massif, the ice shelf is confined to a channel around $50 \mathrm{~km}$ wide. After that the ice shelf widens to the east but is split into a fast flowing portion that ultimately flows past Clemence Massif on the west side, and a slower moving section on the east side. Once past Clemence Massif, the fast flow begins to diverge. It would seem that the ice shelf north of Clemence Massif transfers far less lateral resistance, so that the importance of ice shelf changes closer to the grounding line known from flowline models (Walker et al., 2008; Gagliardini et al., 2010) is amplified in this case. 


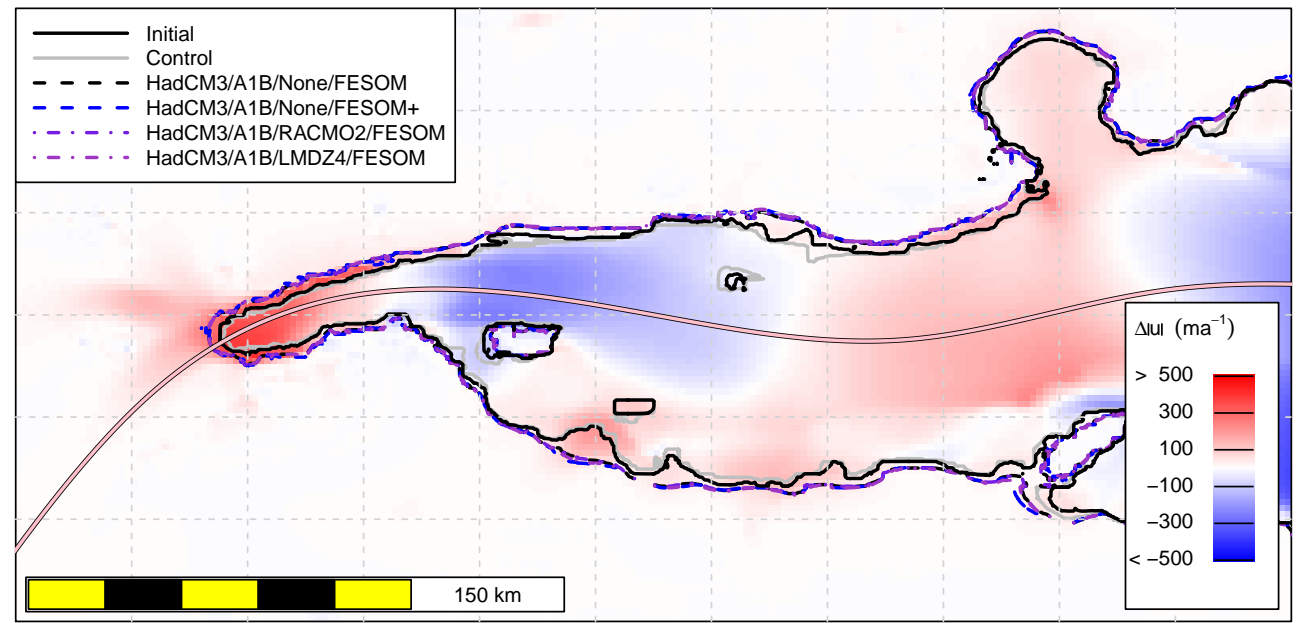

Figure 8. Ice flow acceleration and grounding line migration due to climate model forcing. The difference between final and initial ice flow speed $(\Delta|u|(x, y)=|u(x, y, t=2200)|-\mid u(x, y, t=1982 \mid))$ is shown for the HadCM3/A1B/None/FESOM experiment and exhibits acceleration of the Lambert, Fisher and Mellor glaciers and a mixture of acceleration and deceleration across the ice shelf. Initial and year 2200 grounding lines are shown for the simulations that have melt rates and surface mass balance data up to that point. The control shows advance in some regions while all four of the A1B/FESOM-forced runs retreat in the same way.

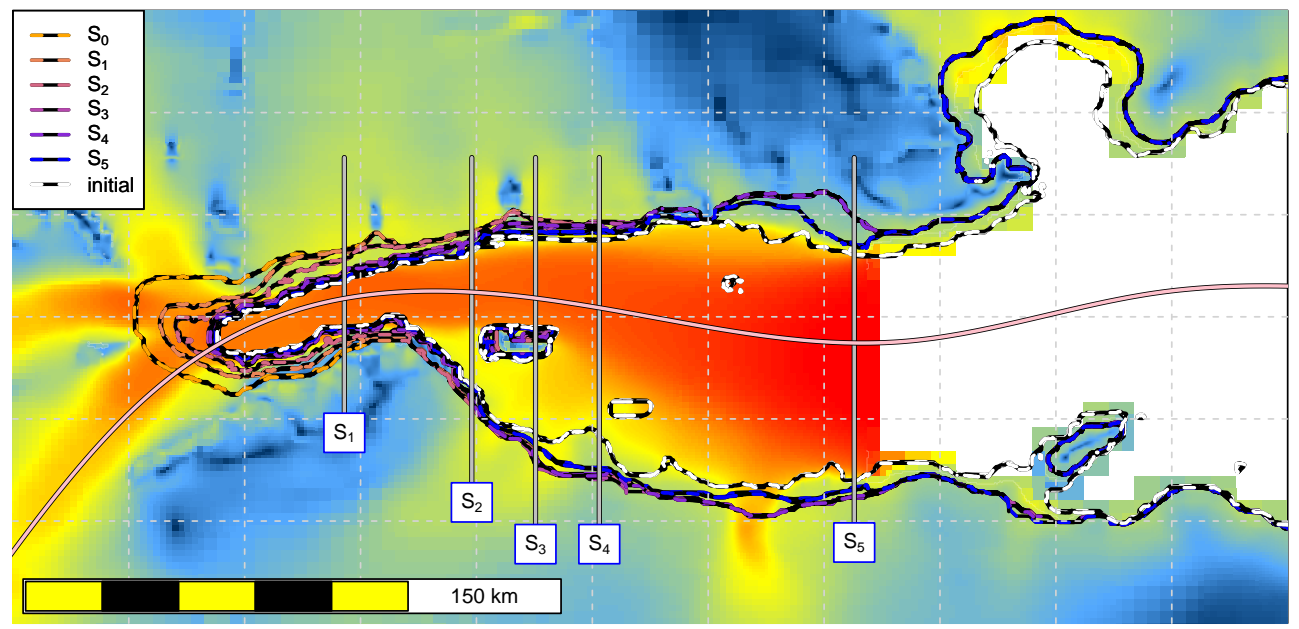

Figure 9. Grounding line migration due to extreme forcing. Initial and year 2200 grounding lines are shown for all of the partial ice-shelf removal experiments. Despite the removal of the northern $25000 \mathrm{~km}^{2}$ of ice shelf, experiment $\mathrm{S}_{5}$ (whose initial ice flow speed is also shown) exhibits little retreat in the southern reaches. Likewise $S_{4}$ and $S_{3}$, even though a further $10000-12500 \mathrm{~km}^{2}$ region of the shelf disappears. $S_{2}$ removes another $2500 \mathrm{~km}^{2}$, from the region east and west of Clemence Massif, and the grounding line retreats $25 \mathrm{~km} . \mathrm{S}_{1}$ and $\mathrm{S}_{0}$ (which remove the entire ice shelf each year) show progressively greater retreat.

In each of the extreme ice-shelf removal experiments, the rate of mass loss decays throughout the simulation, leading us to think that the ice streams are tending towards stable configurations. Similarly, Fig. 6 shows that in the $\mathrm{S}_{0}$ experiment all of the grounding line's motion took place in the first 50 years. Stable ice streams are to be expected given the topography around the present-day grounding line. Figure 1 shows the present-day grounding line lies on a prograded slope, that is, on a bed that slopes down towards the trough underneath the ice shelf along the whole of its length. Such prograded slopes can be seen for $50 \mathrm{~km}$ or more upstream of the grounding line. There are mild retrograde slopes further upstream in the Lambert, Mellor, and Fisher glaciers, so that marine ice sheet instability could be important for retreat over longer timescales, and it might have been important in the past: there is a region of retrograde slope underneath the ice shelf stretching from the southern tip to Clemence Massif. 


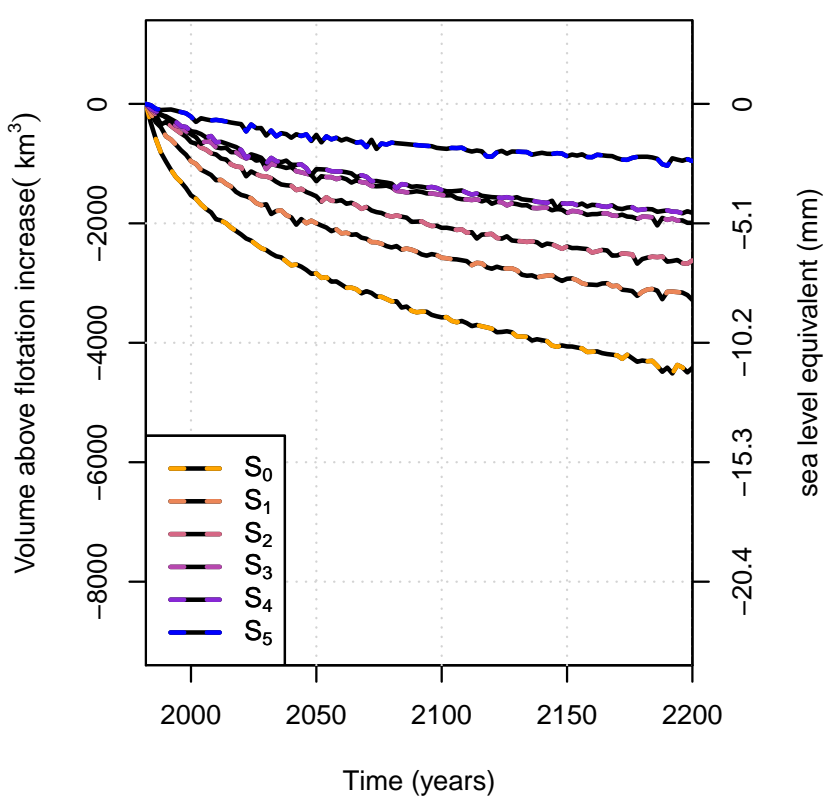

Figure 10. Evolution of the volume above flotation due to extreme forcing. All of the extreme sensitivity experiments result in loss of grounded ice, from $1 \mathrm{~mm}$ sea level rise for experiment $S_{5}$ to $11 \mathrm{~mm}$ for experiment $S_{0}$. Experiment $S_{3}$ removes $2500 \mathrm{~km}^{2}$ more from the ice shelf than $S_{4}$, yet the two experiments show the same trend in volume above flotation ( $3 \mathrm{~mm}$ sea level rise by 2200). Experiment $\mathrm{S}_{2}$ removes a further $2500 \mathrm{~km}^{2}$, from around Clemence massif, to much greater effect $(6 \mathrm{~mm})$.

\subsection{Contribution to global sea level change}

Sea level change in our simulations is modest and the variation between them is dominated by contributions from surface mass balance (Fig. 7). All of the climateforced experiments lead to between 340 and $1130 \mathrm{~km}^{3}$ VAF increase (up to $3 \mathrm{~mm}$ sea level fall) by 2100 , with the exception of the HadCM3/A1B/LMDZ4/FESOM and HadCM3/E1/LMDZ4/FESOM calculations, which lead to around $2000 \mathrm{~km}^{3}$ VAF increase $(5 \mathrm{~mm}$ sea level fall). Those two apply much larger accumulation anomalies over the drainage basin (see Table 1) $-14.5 \mathrm{~km}^{3} \mathrm{a}^{-1}$ on average between 2000 and 2100 , compared to $4.5 \mathrm{~km}^{3} \mathrm{a}^{-1}$ for the next largest anomaly, ECHAM5/A1B/RACMO2. There are no ECHAM5 simulations for the 22nd century, but the differences between the remaining simulations are again due to changes in surface mass balance. HadCM3/A1B/LMDZ4 increases its accumulation anomaly to $50.6 \mathrm{~km}^{3} \mathrm{a}^{-1}$ leading to $6200 \mathrm{~km}^{3}$ VAF increase $(15 \mathrm{~mm}$ sea level fall), while HadCM3/A1B/RACMO applies only $12.4 \mathrm{~km}^{3} \mathrm{a}^{-1}$, leading to $1400 \mathrm{~km}^{3}$ VAF increase (4 mm sea level fall). The difference between the two results essentially equals the cumulative difference between accumulation anomalies. The same observation is true of the two E1 simulations.

We can estimate an upper contribution to sea level rise by considering the most extreme of the ice-shelf removal exper- iments. Experiment $\mathrm{S}_{0}$ led to $3500 \mathrm{~km}^{3} \mathrm{VAF}$ decrease $(9 \mathrm{~mm}$ sea level rise) over 120 years, and $4500 \mathrm{~km}^{3}$ VAF decrease ( $11 \mathrm{~mm}$ sea level rise) over 220 years, even though the entire present-day ice shelf was removed, and newly floating regions that formed during the course of the simulation were treated in the same way (Fig. 10).

\section{Conclusions}

A high-resolution ice flow model of the Amery Ice Shelf drainage basin indicates that it will be rather stable in the face of future warming. We used the BISICLES adaptive mesh ice sheet model to compute its response to changes in surface mass balance and sub ice-shelf melt-rate anomalies provided by two high-resolution atmosphere models (RACMO2 and LMDZ4) and one high-resolution ocean model (FESOM), in turn driven by two global climate models (HadCM3 and ECHAM5) and two future emissions scenarios (E1 and A1B). Although the ocean model predicted a fivefold increase in melt rate in the 22nd century, the resulting dynamic thinning of the tributary glaciers led to no more than $3 \mathrm{~mm}$ sea level rise over 220 years, while the increased snowfall in the region led to up to $15 \mathrm{~mm}$ sea level fall.

The Lambert, Fisher, and Mellor glaciers are most sensitive to thinning of the ice shelf south of Clemence Massif. If the calving front is moved to an east-west line anywhere north of the massif, we compute only a $5 \mathrm{~km}$ grounding-line retreat, but if the front is moved to just south of the massif we see a $25 \mathrm{~km}$ grounding-line retreat. Placing the calving run progressively further south leads to up to $40 \mathrm{~km}$ of grounding-line retreat and $11 \mathrm{~mm}$ sea level rise, but in each case the grounding line stabilizes before the end of the calculation. We attribute the step change to a change in width of the ice shelf around Clemence Massif, and the stability to a bedrock that slopes down towards the ice shelf along the length of the grounding line and for tens of kilometres upstream.

Acknowledgements. This work is Ice2Sea publication no. 180 and the climate model data used in this paper was provided through the Ice2Sea project. This publication is contribution no. 44 of the Nordic Centre of Excellence SVALI, Stability and Variations of Arctic Land Ice, partly funded by the Nordic Top-level Research Initiative. This work was funded in part by the UK Natural Environment Research Council National Centre for Earth Observation. Calculations were carried out on the University of Bristol's Blue Crystal Phase 2 HPC facility. BISICLES development is led by D. F. Martin at Lawrence Berkeley National Laboratory, California, USA, and S. L. Cornford at the University of Bristol, UK, with financial support provided by the US Department of Energy and the UK Natural Environment Research Council.

Edited by: F. Pattyn 


\section{References}

Agosta, C., Favier, V., Krinner, G., Gallée , H., Fettweis, X., and Genthon, C.: High-resolution modelling of the Antarctic surface mass balance, application for the twentieth, twenty first and twenty second centuries, Clim. Dynam., 41, 3247-3260, doi:10.1007/s00382-013-1903-9, 2013.

Bassis, N. J., Coleman, R., Fricker, H. A., and Minster, J. B.: Episodic propagation of a rift on the Amery Ice Shelf, East Antarctica, Geophys. Res. Lett., 32, L06502, doi:10.1029/2004GL022048, 2005.

Budd, W. F., Landon-Smith I. H., and Wishart, E.: The Amery Ice Shelf, in: Physics of Snow and Ice. Proceedings of the International Conference on Low Temperature Science. I (1), edited by: Oura, H., Institute of Low Temperature Science, Hokkaido University, Sapporo, 447-467, 1967.

Colella, P., Graves, D. T., Johnson, J. N., Johansen, H. S., Keen, N., Ligocki, T. J., Martin, D. F., McCorquodale, P., Modiano, D., Schwartz, P., Sternberg, T., and Straalen, B. V.: Chombo Software Package for AMR Applications - Design Document, Applied Numerical Algorithms Group Computational Research Division Lawrence Berkeley National Laboratory Berkeley, CA, USA, 2013.

Cornford, S. L., Martin, D. F., Graves, D. T., Ranken, D. F., Le Brocq, A. M., Gladstone, R. M., Payne, A. J., Ng, E. G., and Lipscomb, W. H.: Adaptive mesh, finite volume modeling of marine ice sheets, J. Comput. Phys., 232, 529-549, doi:10.1016/j.jcp.2012.08.037, 2013.

Dupont, T. K. and Alley, R.: Assessment of the importance of ice shelf buttressing to ice-sheet flow, Geophys. Res. Lett., 32, L04503, doi:10.1029/2004GL022024, 2005.

Fricker, H. A., Hyland, G., Coleman, R., and Young, N. W.: Digital Elevation Models for the Lambert Glacier - Amery Ice Shelf system, East Antarctica, from ERS-1 satellite radar altimetry, J. Glaciol., 46, 553-560, doi:10.3189/172756500781832639, 2000.

Fricker, H. A., Young, N. W., Allison, I., and Coleman, R.: Iceberg calving from the Amery Ice Shelf, East Antarctica, Ann. Glaciol., 34, 241-246, doi:10.3189/172756402781817581, 2002.

Gagliardini, O., Durand, G., Zwinger, T., Hindmarsh, R. C. A., and Le Meur, E.: Coupling of ice-shelf melting and buttressing is a key process in ice-sheets dynamics: ice-shelf melting and buttressing, Geophys. Res. Lett., 37, L14501, doi:10.1029/2010GL043334, 2010.

Galton-Fenzi, B. K., Hunter, J. R., Coleman, R., Marsland, S. J., and Wamer, R. C.: Modeling the basal melting and marine ice accretion of the Amery Ice Shelf, J. Geophys. Res., 117, C09031, doi:10.1029/2012JC008214, 2012.

Hambrey, M. J. and Dowdeswell, J. A.: Flow regime of the Lambert Glacier-Amery Ice Shelf system, Antarctica: Structural evidence from Landsat imagery, Ann. Glaciol., 20, 401-406, doi:10.3189/172756494794586943, 1994.

Haran, T., Bohlander, J., Scambos, T., Painter, T., and Fahnestock, M. (compilers): MODIS mosaic of Antarctica (MOA) image map, National Snow and Ice Data Center, Boulder, Colorado, USA, doi:10.7265/N5ZK5DM5, 2005 (updated 2006).

Holt, J. W., Blankenship, D. D., Morse, D. L., Young, D. A., Peters, M. E., Kempf, S. D., Richter, T. G., Vaughan, D. G., and Corr, H. F. J.: New boundary conditions for the West Antarctic Ice Sheet: Subglacial topography of the Thwaites and
Smith glacier catchments, Geophys. Res. Lett., 33, L09502, doi:10.1029/2005GL025561, 2006.

Hooke, R. LeB: Flow law for polycrystalline ice in glaciers: Comparison of theoretical predictions, laboratory data, and field measurements, Rev. Geophys., 19, 664-672, doi:10.1029/RG019i004p00664, 1981.

Huybrechts, P. and de Wolde, J.: The Dynamic Response of the Greenland and Antarctic Ice Sheets to Multiple-Century Climatic Warming, J. Climate., 12, 2169-2188, doi:10.1175/15200442(1999)012<2169:TDROTG>2.0.CO;2, 1999.

Joughin, I., Rignot, E., Rosanova, C. E., Lucchitta, B. K., and Bohlander, J.: Timing of Recent Accelerations of Pine Island Glacier, Antarctica, Geophys. Res. Lett., 30, 1706, doi:10.1029/2003GL017609, 2003.

Joughin, I., Tulaczyk, S., Bamber, J. L., Blankenship, D., Holt, J. W., Scambos, T., and Vaughan, D. G.: Basal conditions for Pine Island and Thwaites Glaciers, West Antarctica, determined using satellite and airborne data, J. Glaciol, 55, 245-257, 2009.

Larour, E., Rignot, E., and Aubry, D.: Modelling of rift propagation on Ronne Ice Shelf, Antarctica, and sensitivity to climate change, Geophys. Res. Lett., 31, L16404, doi:10.1029/2004GL020077, 2004.

Le Brocq, A. M., Payne, A. J., and Vieli, A.: An improved Antarctic dataset for high resolution numerical ice sheet models (ALBMAP v1), Earth Syst. Sci. Data, 2, 247-260, doi:10.5194/essd-2-247-2010, 2010.

Ligtenberg, S. R. M., van de Berg, W. J., van den Broeke, M. R., Rae, J. G. L., and van Meijgaard, E.: Future surface mass balance of the Antarctic ice sheet and its influence on sea level change, simulated by a regional atmospheric climate model, Clim. Dynam., 41, 867-884, doi:10.1007/s00382-013-1749-1, 2013.

Lythe, M. B., Vaughan, D. G., and the BEDMAP Consortium: BEDMAP: A new ice thickness and subglacial topographic model of Antarctica, J. Geophys. Res.-Sol. Ea., 106, 1133511351, doi:10.1029/2000JB900449, 2001.

MacAyeal, D. R.: The Basal Stress Distribution of Ice Stream E, Antarctica, Inferred by Control Methods, J. Geophys. Res., 97, 595-603, doi:10.1029/91JB02454, 1992.

MacAyeal, D. R., Okal, E. A., Aster, R. C., Bassis, J. N., Brunt, K. M., Cathles, L. M., Drucker, R., Fricker, H. A., Kim, Y., Martin, S., Okal, M. H., Sergienko, O. V., Sponsler, M. P., and Thom, J. E.: Transoceanic wave propagation links iceberg calving margins of Antarctica with storms in tropics and Northern Hemisphere, Geophys. Res. Lett., 33, L17502, doi:10.1029/2006GL027235, 2006.

Morlighem, M., Rignot, E., Seroussi, H., Larour, E., Ben Dhia, H., and Aubry, D.: Spatial patterns of basal drag inferred using control methods from a full-Stokes and simpler models for Pine Island Glacier, West Antarctica, Geophys. Res. Lett., 37, L14502, doi:10.1029/2010GL043853, 2010.

Morlighem, M., Rignot, E., Seroussi, H., Larour, E., Ben Dhia, H., and Aubry, D.: A mass conservation approach for mapping glacier ice thickness, Geophys. Res. Lett., 38, L19503, doi:10.1029/2011GL048659, 2011.

Pattyn, F.: Antarctic subglacial conditions inferred from a hybrid ice sheet/ice stream model, Earth. Planet. Sc. Lett., 295, 451-461, doi:10.1016/j.epsl.2010.04.025. 2010.

Rignot, E. and Thomas, R. H.: Mass Balance of Polar Ice Sheets, Science, 297, 1502-1506, doi:10.1126/science.1073888, 2002. 
Rignot, E., Mouginot, J., and Scheuchl, B.: Ice Flow of the Antarctic Ice Sheet, Science, 521, 1427-1430, 2011.

Scambos, T. A., Hulbe, C., Fahnestock, M., and Bohlander, J.: The link between climate warming and break-up of ice shelves in the Antarctic Peninsula, J. Glaciol., 46, 516-530, doi:10.3189/172756500781833043, 2000.

Scambos, T. A., Haran, T. M., Fahnestock, M. A., Painter, T. H., and Bohlander, J.: MODIS-based Mosaic of Antarctica (MOA) data sets: Continent-wide surface morphology and snow grain size, Remote Sens. Environ., 111, 242-257, doi:10.1016/j.rse.2006.12.020, 2007.

Schoof, C. and Hindmarsh, R. C. A.: Thin-film flows with wall slip: an asymptotic analysis of higher order glacier flow models, Quart. J. Mech. Appl. Math., 63, 73-114, doi:10.1093/qjmam/hbp025, 2010.

Seroussi, H., Morlighem, M., Rignot, E., Larour, E., Ben Dhia, H., Aubry, D., and Kristensen, S. S.: Ice flux divergence anomalies on 79north Glacier, Greenland, Geophys. Res. Lett., 38, L09501, doi:10.1029/2011GL047338, 2011.

Shepherd, A., Wingham, D. J., and Mansley, J. A. D.: Inland thinning of the Amundsen Sea sector, West Antarctica, Geophys. Res. Lett., 29, 1364, doi:10.1029/2001GL014183, 2002.

Shepherd, A., Ivins, E., Geruo, A., Barletta, V., Bentley, M., Bettadpur, S., Briggs, K., Bromwich, D., Forsberg, R., Galin, N., Horwath, M., Jacobs, S., Joughin, I., King, M., Lenaerts, J., Li, J., Ligtenberg, S., Luckman, A., Luthcke, S., McMillan, M., Meister, R., Milne, G., Mouginot, J., Muir, A., Nicolas, J., Paden, J., Payne, A., Pritchard, H., Rignot, E., Rott, H., Sorensen, L., Scambos, T., Scheuchl, B., Schrama, E., Smith, B., Sundal, A., van Angelen, J., van de Berg, W., van den Broeke, M., Vaughan, D., Velicogna, I., Wahr, J., Whitehouse, P., Wingham, D., Yi, D., Young, D., and Zwally, H.: A Reconciled Estimate of Ice-Sheet Mass Balance, Science, 338, 1183-1189, doi:10.1126/science.1228102, 2012.

Skvarca, P., Rack, W., and Rott, H.: 34 year satellite time series to monitor characteristics, extent and dynamics of Larsen B, Antarctic Peninsula, Ann. Glaciol., 29, 255-260, 1999.
Timmermann, R. and Helmer, H. H., : Southern Ocean warming and increased ice shelf basal melting in the 21 st and 22 nd centuries based on coupled ice-ocean finite element modelling, European Geosciences Union General Assembly 2013, Vienna, 7-12 April, 2013.

van den Broeke, M. R., Bamber, J., Ettema, J., Rignot, E., Schrama, E., van de Berg, W. J., van Meijgaard, E., Velicogna, I., and Wouters, B.: Partitioning recent Greenland mass loss, Science, 326, 984-986, doi:10.1126/science.1178176, 2009.

Vaughan, D. G., Corr, H. F. J., Ferraccioli, F., Frearson, N., O'Hare, A., Mach, D., Holt, J., Blankenship, D., Morse, D., and Young, D. A.: New boundary conditions for the West Antarctic ice sheet: subglacial topography beneath Pine Island Glacier, Geophys. Res. Lett., 33, L09501, doi:10.1029/2005GL025588, 2006.

Walker, R. T., Dupont, T. K., Parizek, B. R., and Alley, R. B.: Effects of basal-melting distribution on the retreat of ice-shelf grounding lines, Geophys. Res. Lett., 35, L17503, doi:10.1029/2008GL034947, 2008.

Wen, J., Jezek, K. C., Monaghan, A. J., Sun, B., Ren, J., and Huybrechts, P.: Accumulation variability and mass budgets of the Lambert Glacier-Amery Ice Shelf system at high elevations, Ann. Glaciol., 43, 351-360, 2006.

Wen, J., Wang, Y., Liu, J., Jezek, K. C., Huybrechts, P., Csatho, B. M., Farness, P., and Sun, B.: Mass budget of the grounded ice in Lambert Glacier-Amery Ice Shelf system, Ann. Glaciol., 48, 193-197, 2008.

Wen, J., Wang, Y., Wang, W., Jezek, K. C., Liu, H., and Allison, I.: Basal melting and freezing under the Amery Ice Shelf, East Antarctica, J. Glaciol., 56, 81-90, doi:10.3189/002214310791190820, 2010.

Williams, M. J. M., Grosfeld, K., Warner, R. C., Gerdes, R., and Determann, J.: Ocean circulation and ice-ocean interaction beneath the Amery Ice Shelf, Antarctic, J. Geophys. Res., 106, 22383 22399, doi:10.1029/2000JC000236, 2001.

Yu, J., Liu, H., Jezek, K. C., Warner, R. C., and Wen, J.: Analysis of velocity field, mass balance, and basal melt of the Lambert Glacier-Amery Ice Shelf system by incorporating Radarsat SAR interferometry and ICESat laser altimetry measurements, J. Geophys. Res., 115, B11102, doi:10.1029/2010JB007456, 2010. 